\title{
Announcement In memoriam: Professor Brian Maurice John Foxwell, 1956 to 2008
} Fionula Brennan and Marc Feldmann

The Kennedy Institute of Rheumatology, Faculty of Medicine, Imperial College London, Aspenlea Road, London W6 8LH, UK

Corresponding author: Fionula Brennan, f.brennan@imperial.ac.uk

Published: 27 February 2009

This article is online at http://arthritis-research.com/content/11/1/104 (c) 2009 BioMed Central Ltd

Professor Brian Foxwell, Professor of Immune Cell Signalling at Imperial College and a senior investigator at the Kennedy Institute of Rheumatology, unexpectedly passed away on 17 December, 2008. Brian Foxwell received his $\mathrm{PhD}$ from the University of Bristol in 1981, followed by a post doctorate at the Imperial Cancer Research Fund (now Cancer Research UK), where he worked with Andy Creighton and Phil Thorpe on the development of monoclonal antibodies as drugtargeting agents for cancer therapy. This awakened his interests in the huge potential of new technology in therapeutics; this led to Brian spending 3 years in industry at Sandoz, Basle with Bernard Ryffel, investigating the molecular action of cyclosporin. His time in industry was very educational, but his personality was not suited to this occupation. He was reluctant to agree routinely to his superiors' and elders' opinions. Hence, in 1989 Marc Feldmann recruited Brian Foxwell to the Kennedy Institute of Rheumatology, where rheumatoid arthritis (RA) provided a natural focus for Brian's interest in inflammation, mediators, and eventually cytokine signal transduction mechanisms and their relationships to molecular pathology, drug target identification and the development of new therapies. Brian remained at the Kennedy Institute of Rheumatology for 21 years, where his career flourished. This period saw the integration of the Institute within the Imperial College Faculty of Medicine. Brian was promoted to Senior Lecturer at Imperial College in 1996 and to Professor of Immune Cell Signalling in 1999. His interest and expertise in inflammation led to him being appointed as Associate Editor to Arthritis Research and Therapy from 2006.

Brian's research interests and accomplishments were wide ranging, and this enabled him to see links between different projects. He was not interested in the latest fashions, and he had strong views about the correct approaches to science. Two particular examples of approaches that he fought against was the use of transformed cell lines as models for use in cell signalling studies. He argued that with abnormal chromosome composition and hence huge genetic differences from normal cells, and cells dividing much faster than normal, how
Arthritis Research \& Therapy 2009, 11:104 (doi:10.1186/ar2628)

could their signalling pathways be representative? His major research contributions have resulted in the development of pioneering new approaches, for example using adenoviral vectors to induce transgene expression in primary cells that have traditionally been difficult to transfect. This technology was used to elucidate signal transduction mechanisms in primary cells and RA disease tissue. Professor Foxwell showed that there was heterogeneity in the signals that regulate tumour necrosis factor expression in human macrophages and those in diseased RA tissue, some being highly dependent on nuclear factor- $\kappa B$ and others much less so. This technology was used widely in his research activities and included identifying the target of action of STAT3 (signal transducer and activator of transcription 3) in interleukin-10 signalling using adenovirus-based tumour necrosis factor promoter constructs, as well as defining a new approach to vaccines by incorporating signals that activate the immune system (adjuvants) and the epitopes into one construct.

More recently, Professor Foxwell developed an interest in what was then an emerging family of innate immune receptors, the Toll-like receptors (TLRs). He considered the possible involvement of these receptors in the pathology of RA, and studies using the adenoviral technology in RA diseased tissue provided strong evidence that TLRs do play a role in $\mathrm{RA}$, and that these receptors could prove to be therapeutic targets in the future. A similar approach led to his discovery that members of the Tec family of tyrosine kinases are essential for cytokine production in response to TLR ligands a finding that may also have therapeutic implications for a number of inflammatory conditions.

It is a great shame that his untimely death has inhibited the full flowering of his creativity. We will never know what he might have achieved if his research career had not been interrupted.

His research studies resulted in more than 150 publications, many patents and much international recognition. He was awarded an FRCPath by the Royal College of Pathologists in 2005 and a DSc from the University of Bristol in 2006. 


\section{Figure 1}

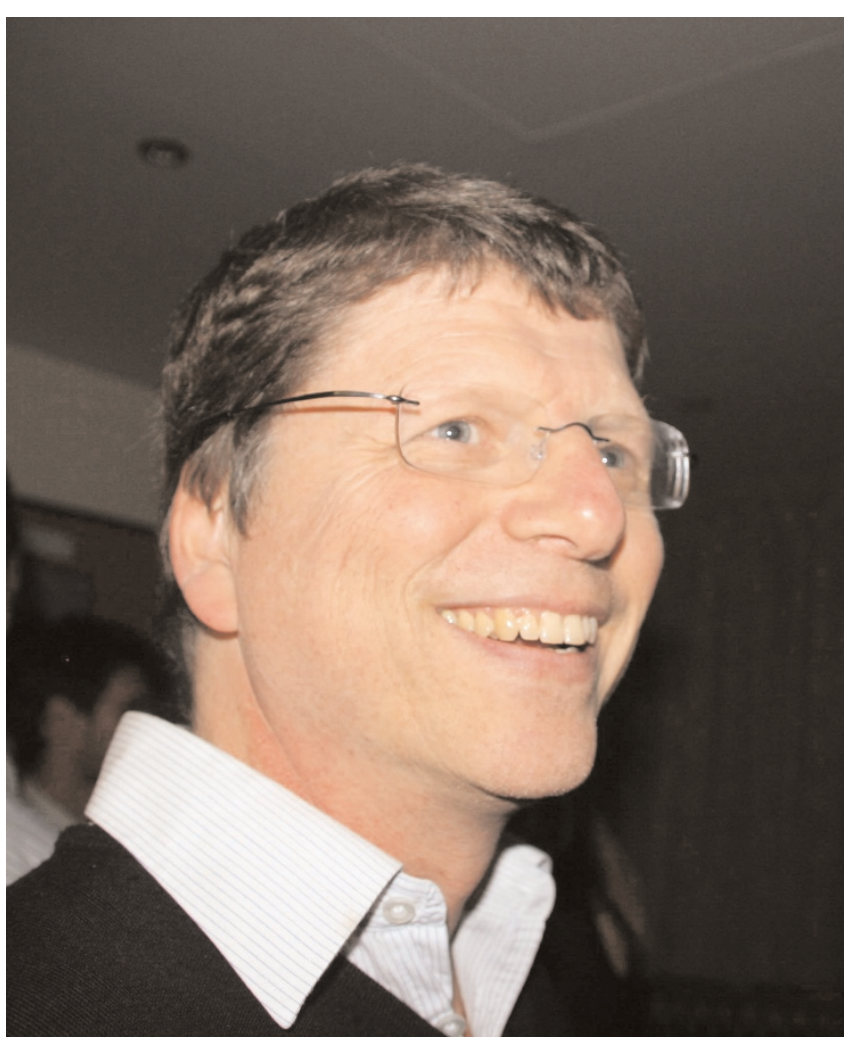

Professor Brian Maurice John Foxwell, 1956 to 2008.

Brian had many interests outside science, including philosophy, religion, politics and football; he was a passionate Chelsea fan, and his ability to discuss the details of the latest match was legendary. He is survived by his wife Karen, to whom he was married for 23 years, and his three children, Kim, Kristen and John, of whom he was very proud. His family were all well known at the Kennedy Institute, particularly his two daughters, who had spent summer vacations working at the Institute. Kim was instrumental in setting up an Institute archive for laboratory books and Kristen was a prize-winning Nuffield summer scholar, investigating inflammatory signalling in adipose tissue.

Brian will be greatly missed by his many friends and colleagues throughout the Kennedy Institute and further afield. He leaves behind a team of extremely active and enthusiastic researchers at the Kennedy Institute, whose careers have been indelibly shaped by his untiring enthusiasm for science and his ability to see 'the wood for the trees'. They continue to pursue many of the recent projects that Brian initiated. 